\title{
THE INFLUENCE OF BIBLICAL TEXTS UPON ENGLISH LAW.*
}

The subject of this address, "The Influence of Biblical Texts Upon English Law," must appear peculiarly unattractive. It suggests upon one hand a sermon, on the other hand a law lecture; and if there is anything less alluring than a sermon, especially on a week-day, it would be a lecture on law; and if there is anything more repellant than a lecture on law, I suppose it would be a sermon. The combination would be deadly. It was probably for this reason that the committee in charge of this performance did not announce my subject in advance, so I can only give you this brief warning of what you will have to endure. After this, in Biblical phrase, your blood be upon your own head; in legal language, volenti non fit injuria-that is, no one can complain who is willing to be hurt.

At the outset it may be proper to say what excuse there may be for selecting such a subject for a Phi Beta Kappa address.

The object of our Society is stated in its Constitution to be the promotion of literature, and our motto indicates that philosophy, including religion and ethics, is worthy of cultivation as the guide of life. In selecting a topic for this address I felt that I must not wander too far from this profession of faith, and yet that for practical reasons I was restricted to some subject within the narrower orbit of my own profession. But in a way the study of law will, especially when undertaken from its historical side, inevitably lead, through more or less devious windings, into the whole world of learning and literature-for law is the system of rules governing the conduct of men as members of society

\footnotetext{
*An address delivered before the Phi Beta Kappa and Sigma xi Societies of the University of Pennsylvania on June 14, IgIo.
} 
and their reciprocal rights and duties. The study of the law, therefore, touches and surrounds the problems of history, politics, social economics, ethics, religion and philosophy, as the air which we breathe without feeling its weight envelops the earth and all who dwell thereon. It is a strictly historical science, the product of centuries of development and evolution, and like natural science exhibits a continuous adaptation to surrounding circumstances, with consequent diversification and improvement, leading from lower up to higher and better forms. As has been pointed out, and perhaps the comparison may reconcile the members of the Sigma Xi to the subject of this paper, "the general facts - upon which the theory of evolution by natural selection rests, namely, the struggle for existence, the survival of the fittest and heredity, have all of them their parallels or analogies in the realm of Jurisprudence."

Our law is not like Melchisedec-"without father, without mother, without genealogy, having neither beginning of days nor end of life." The law, like everything we do and like everything we say, is a heritage from the past.

Sir Francis Bacon long ago said, "The law of England is not taken out of Amadis de Gaul, nor the Book of Palmerin, but out of the Scripture, out of the laws of the Romans and Grecians." And again he said, "Our laws are as mixed as our language."

So just as our English language has sprung from AngloSaxon, Teutonic, French, Latin and Greek roots, our English common law with its unsurpassed powers of assimilation, elimination and expansion, has its origins in old local customs, the civil law, the canon law of the Church, the writings of philosophers and texts of Scripture, interwoven with the accumulation of a thousand years of statutes and judicial decisions. To speak in a parable, it is like the air plant which grows by the wayside in Bermuda, and even when torn from its native soil still keeps on growing, deriv- 
ing its nutrition from every one of the four winds of Heaven; or, again, like the banyan tree, its branches wherever they touch the earth take fresh root and spring anew.

Now every man is presumed to know the law. Bentham, in speaking of judge-made law, called it "dog law." "Do you know," said he, "how they make it? Just as a man makes laws for his dog. When your dog does anything you want to break him of, you wait until he does it, and then beat him for it. This is the way you make laws for your dog; and this is the way the judges make law for you and me." Nevertheless, you are all supposed to know the law, and likewise you are all supposed to know the Bible. What I am to say, therefore, about a certain connection between the law and the Bible is theoretically supposed to be entirely familiar to you, and indeed to say that the Bible in many ways has exerted a mighty influence on our law is a platitude so profound that I can scarcely hope to be excused for having uttered it.

This influence has been manifested in several very distinct ways, with only one of which we shall deal this afternoon.

First, of course, there is the general influence of the Bible through the medium of the Christian religion upon the law. It has been often said, indeed, that Christianity is part of the common law of England, and this is due in great measure to the authority of Sir Matthew Hale (King v. Taylor, I Vent. 293, 3 Keble 507), Blackstone and other writers, while Lord Mansfield held (Chamberlain of London v. Evans, I767) that the essential principles of revealed religion are part of the common law. The former proposition has some support also in the decisions of our own State, but in its broad and general sense is without adequate foundation, as has been frequently demonstrated. There can be, however, no doubt that the principles of the Christian religion have profoundly affected the law. Christianity sup- 
plied, as it were, the atmosphere of public opinion which surrounded the English people, the legislature and the courts, but its precise effect would be an almost impossible task to determine.

Of course, the Ten Commandments will occur to every one as examples of Biblical laws which were adopted into our own. Disbelief in God, as well as disbelief in Christ, Blasphemy, Sabbath Desecration, Theft, Adultery, Homicide, Perjury, to mention the chief offences, were either punished by the spiritual or the civil courts, or by both. The history of heresy alone in England, with all that it involved, the hatreds, the persecutions, the judicial murders which it narrates, forms one of the saddest chapters in human history. With none of this are we concerned at present.

Second, there is the special influence of the Church and the law of the Church upon the common law.

We who live in modern times when the State is the supreme and only source of law, and the Church is absolutely deprived of temporal authority, find it hard to realize that for many centuries the Church exercised an authority quite as important as that of the State, that its jurisdiction extended over and regulated the minutest details of the daily life of every man, and that its laws were administered by courts whose sentence of excommunication practically cut off the culprit from all rights and privileges as a member of society. He could not be a juryman, a witness nor a suitor in the civil courts, and if pertinacious could be kept in prison indefinitely. The ecclesiastical courts of England have a longer pedigree than those of the common law; for the Church, of which they formed the judicial branch antedated the Conquest, and through the Church courts the Popes exerted their authority over all Christendom. The canon lawyers compiled a great system of law, only comparable to that of the Roman or civil law, and this law was 
held by the Church to be superior to the common law of the land, just as the Church claimed superiority over the State, and the Pope over the King. Even after the Reformation, when Henry VIII boldly asserted the royal supremacy, the canon law of the Catholic Church became the King's ecclesiastical law of the Church of England. The Church courts exercised a corrective jurisdiction over the religious beliefs and morals of both the clergy and laity. All matrimonial questions were settled in these courts, they also granted probate of wills and letters of administration, and to a great extent controlled executors and administrators.

This law of the Church was founded upon the Holy Scriptures as expanded and interpreted by the decrees of the Popes and the glosses of commentators. Its influence upon the system of the common law was greater than is generally supposed, and through it the Bible has had much indirect effect.

But in the third place, and this is the narrower subject of this paper, we find scattered here and there throughout the statutes, law treatises and reports of judicial decisions, many legal rules which were held either to be directly founded upon certain texts of Scripture, or at least profoundly affected and strengthened by them.

The Old Testament was indeed considered as supplemented rather than supplanted by the New, but subject to this qualification, the Bible, although it consisted of not one book, but of many books, written at periods of time far removed from one another, and from different points of view, in divers tongues and in the literary forms peculiar to an ancient and Eastern civilization, was considered as the permanent expression of the divine will, and almost every text as an inspired oracle for the guidance of all men in all countries and at all times. Interpretation and criticism were practically unknown; and the histories of the early Semitic tribes, their prophetic exhortations, their poetry, 
lyric and dramatic, and their laws were all received on the same basis; and a text of the Bible, wherever it might be found, and whatever might be its logical connection, was regarded as an infallible authority. Indeed, in the fundamental laws of the Colonies of Massachusetts, Connecticut, New Haven and West New Jersey, the judges were commanded to inflict penalties according to the law of God. The study of the Scriptures was specially associated with the study of law. Chief Justice Fortescue, in his book de Laudibus, said of the judges, that after court "when they. have taken their refreshments they spend the rest of the day in the study of the laws, reading of the Holy Scriptures, and other innocent amusements, at their pleasure."

All through the middle ages, and indeed for long after, men craved authority for all they thought, said and did. The Bible was, of course, first, with the writings of the Fathers of the Church second; but Aristotle, "The Philosopher," especially as his works were reconciled with Christianity through the writings of St. Thomas Aquinas, was followed with almost equal devotion; and many of the Latin poets and Cicero served in default of something better. Virgil was particularly esteemed, being regarded as almost a forerunner of Christianity; indeed St. Paul was supposed to have shed tears over Virgil's tomb in his regret that he had never seen the greatest of the poets in life.

\author{
Ad Maronis mausoleum \\ Ductus fudit super eum \\ Piae rorem lacrimae; \\ 'Quam te', inquit, 'reddidissem' \\ 'Si te vivum invenissem,' \\ 'Poetarum maxime.'
}

We will now consider briefly some of the more striking instances of the influence exercised by specific texts.

That husband and wife are in law one person was an axiom of the common law, and the old joke was that the 
one person was the husband. "This is now bone of my bones and flesh of my flesh;" * * * "And they shall be one flesh," Gen. $2: 23$. Such texts as these and the inferior position of the wife in the Old Testament had a powerful effect upon the law of married women. The law of the Church followed these texts, and, by emphasizing the sacramental character of the marriage relation, produced a result which harmonized well with the feudal system. For many centuries the laws governing married women in regard to the marriage bond itself, her dealings with the outside world in matters of contract and of tort, her capacity to own real and personal property, were all grounded upon this theory, and so continued until very recent times.

Another text which had great importance in the law of marriage was that in Matthew I9:6-9, Mark Io:9, where Christ, after repeating the text from Genesis, added, "What therefore God hath joined together let no man put asunder," to which he added the rule which is understood to allow divorce only on the ground of infidelity. These commands of Christ, given also in the Sermon on the Mount and contained besides in the Gospel of St. Luke, are the foundation of our law of marriage.

The political thought of the Middle Ages affords a curious instance of the application of Biblical texts to the theory of a corporation. A body corporate was a phrase which instantly suggested or was, perhaps, suggested by the language of St. Paul in speaking of the Church as Christ's body-"We being many are one body in Christ," Romans I2:4, 5; "Now ye are the body of Christ and members in particular," I Corinthians I2:27. Indeed the whole of that chapter is based upon the comparison, and St. Paul in other of his epistles refers to the same idea, which is reflected in the theory that a corporation is an artificial body composed of divers constituent members, but without a full and independent personality. The most usual corporations were 
of course ecclesiastical, to which St. Paul's metaphor directly applied, but the idea was naturally extended to civil corporations, notably the State itself, and then generally to all. The members of a corporation were its limbs, its offcers were its organs, its franchises were compared to the ligaments. Such a body must have a head or it could not act; the death of an abbot, for example, worked a serious inconvenience. All this entered into the discussion which was waged between the nominalists and realists of the day, whether corporations were real or ideal, actual or fictitious things, and the echoes of the controversy are reverberating to the present time.

Slavery was a matter of course in ancient times in all countries. The Old Testament form of it was particularly mild and humane. In theory, at least, a slave was a member of his master's household, or might become such by having his ear pierced with an awl and thus fastened to the door post. This made his slavery permanent, as it annexed him to the home, or it may be that by the "door post" was meant the gate of the camp or city, which gave formal publicity to the proceeding. And in Deuteronomy, 23:I5, a fugitive slave was to be protected when he fled from his master. St. Paul, on the other hand, sent back Onesimus to his master Philemon, though with an injunction to treat him kindly, and in his Epistle to the Ephesians exhorted slaves to be obedient to their masters. Yet in numerous passages he speaks of the distinction between slave and freeman as having no meaning in their relationship to God. He himself was a bond servant to Christ. The condition of slavery in other words was only external, having no existence in the spiritual life "where there is neither Greek nor Jew, bond nor free, but Christ is all and in all." And on Mars' Hill St. Paul declared that God had made of one blood all nations of men, for in him we live and move and have our being, quoting what the poet Aratus said, "For we are also his offspring." 
The early Fathers and the Church down to modern times recognized slavery in the same way. St. Gregory repeated the theory inherited from the Greek philosophy that all men are by nature equal, and reconciled it with the institution of slavery by holding the latter to be a concession to necessary conditions of human life and one of the consequences of sin. He who commits $\sin$ is the servant of $\sin$.

In the bitter controversies over slavery and the Fugitive Slave Laws which preceded our Civil War, no authority was quoted with greater confidence than was St. Paul, and he who argued against the injustice of slavery was held to be an opponent of the revealed will of God; while on the other hand Emerson in his speech on the Fugitive Slave Law unhesitatingly affirmed that an immoral law was void and appealed for support to the Bible, which he said was a part of every technical law library.

So St. Paul said, "Let every soul be in subjection to the higher powers: the powers that be are ordained of God." "Fear God, honour the King." These and similar texts in later times became the ground of the formal theory of the Divine Right, which made so much mischief in the history of our constitutional law. But in other well-known passages St. Paul holds that the end of civil government is to be the avenger for wrath to him who doeth evil; its divine institution was for that purpose and only so far as that purpose was fulfilled did government retain its sacred character. In short, the Bible contains an arsenal of texts, from which the advocates of the Divine Right on one side, and the defenders of human freedom and equality on the other, freely selected their weapons.

The medieval doctrine of the unlawfulness of usury, that is, the charging of interest for the loan of money, produced a profound impression upon social and economic progress. The texts which forbade it are familiar. Exodus 22:25, and Leviticus $25: 36$ prohibited the exaction of interest from 
the poor, which practically included at that time every one who wanted to borrow; and while the later code of Deut. 23:I9 allowed the Jews to charge interest on loans to foreigners, the XVth Psalm described a citizen of Zion as one who putteth not out his money to usury; and Christ himself in the Sermon on the Mount, Luke 6:34, directed his disciples to lend "hoping for nothing again." Aristotle, moreover, declared that money being by nature barren or unproductive, to extract offspring from it must necessarily be contrary to nature, it being remembered that the Greek word Tokos meant both "child" or "offspring" and derivatively interest. There could be no question as to the iniquity of a practice forbidden by both Aristotle and the Bible, so all through the Middle Ages and long afterwards, usury was regarded with peculiar abhorrence as a mortal sin, although avarice, triumphant over piety, continually evaded the law by ingenious devices. And indeed in those days men borrowed not so much to use money in business or commerce as to relieve pressing necessity; the debtor was a poor man who borrowed as a last resort to support himself and his family, and the creditor in recovering his loan would take all that his victim owned. Money lending, therefore, was left to the Jews, who being without the pale of the Church were not regarded as subject to its laws, and it was thought were damned already, though, of course, the practice was not legal with them any more than it was with Christians. The natural effect was to increase vastly the rate of interest charged in order to insure the contingent losses of an illegal and vastly unpopular business. $\mathrm{He}$ who ran the risk of odium and temporal loss in this world and damnation in the next, naturally made the most while he could out of his iniquitous enterprise, the rates of interest rose to enormous percentages and the restrictions on trade and commerce became, as trade and commerce increased, unbearable. The practical wisdom of Elizabeth's Parliament repealed the 
earlier acts in I3 Elizabeth 8, and avoided all contracts for interest over Io\%.

The curious and horrible history of withcraft in England, Old and New, is due to the misapplication of the well-known text in Exodus 22:18, "Thou shalt not suffer a witch to live." This injunction was reinforced by the references in Deut. I8:9 to sorcerers, charmers and consulters with familiar spirits, and in Levit. 20:27 such offenders were doomed to be stoned. The Hebrews like all ancient people, were profoundly superstitious, and firm believers in such things. Saul himself is stated in I Samuel 28:9 to have driven the wizards and mediums from the country, yet in his last extremity he consulted the Witch of Endor, who procured for him a seance with the prophet Samuel. The evil effects of witchcraft upon a superstitious people may be fairly estimated by what we see in present times of their modern representatives, and the penalty of death, though apparently severe was doubtless not an unreasonable police regulation some eight centuries before Christ. But the command, "Thou shalt not suffer a witch to live," was transplanted to England after an interval of over two thousand years, as though it were intended to apply everywhere and for all time, and "these awful words," says Mr. Lea, in his History of the Inquisition, "have served as a justification for more judicial slaughter than any other sentence in the history of human jurisprudence." Statutes were passed upon the subject during the reign of Henry VIII and Elizabeth, and in the following century James I, who firmly believed in Demonology, procured the passage of a drastic act in the first year of his reign. The best-known examples of persecution for witchcraft were the case of the Lancashire witches in I634, and the case of the Norfolk witches ten years later, in which latter affair about fifty persons were executed. One pathetic feature of this unhappy time is that it was the fervently religious people who believed 
most implicitly in the guilt of the wretched old women who were accused. Sir Matthew Hale was one of the brightest ornaments of the English bench, yet it was he who presided in 1665 at the trial of witches in Bury St. Edmunds, where Sir Thomas Browne, the author of the Religio Medici, gave his expert testimony against the defendants. Bacon, Raleigh, Selden and other famous and brilliant men were all infected with the same terrible error, and in fact the Acts were not repealed until I736.

Blackstone IV, 60, says at a later date, "To deny the possible, nay the actual existence of witchcraft and sorcery is at once flatly to contradict the revealed word of God in various passages both of the Old and New Testament."

"Those who read the testimony as set forth in Hutchinson on Witchcraft, Potts' Discoverie, and the case of Temperance Lloyd in the State Trials, 8, Ior8, will be saddened and amazed at the record of credulity and superstition. In New England the case of the Salem witches is well known, but in Pennsylvania there is no such sad record. Only one trial for witchcraft appears to have taken place in this Province, and in that the verdict was "not guilty," though coupled with a finding that the defendant was guilty of "having the common fame of a witch."

While it would be too much to assert that all of this was due to the Biblical texts referred to, it is certain that for many years doubters were silenced by the supposedly Divine authority.

There was an ancient rule that any, animate or inanimate thing that caused the death of a human being should be deo dandum, that is, "given to God," which in practice meant that the deadly thing or its value was handed over to the King as the price of blood to be, at least theoretically, devoted by his almoner to pious uses, or objects of charity. The law seems to have especially applied in cases when the death was caused by something in motion, like a horse that 
throws its rider, or a cart that runs over a man. Mrs. Green thus describes the law: "If a peasant were kicked by his horse, if in fishing he fell from his boat, or if in carrying home his eels or herrings he stumbled and was crushed by the cart wheel, his wretched children saw horse, or boat or cart with its load of fish, which in olden days had been forfeited as deodand to the service of God, now carried off to the King's Hoard." And for centuries in every indictment for homicide the value of the weapon which caused the death was always stated.

This rule is very ancient and most likely antedated the time when the Bible had any very great influence in shaping the law, but Lord Coke, followed by Blackstone, grounds it expressly upon the law of God as stated in Exodus 21 :28: "If an ox gore a man or a woman that they die, then the ox shall be surely stoned and his flesh shall not be eaten." It is a strange example of the persistence of ancient law that deodands were not abolished in England by statute until 1846. (9 and Io Vict. c. 62.) It is, however, worthy of consideration whether modern conditions do not call for a revival of the law. If every automobile or trolley car, for instance, which causes the death of a man, woman or child, were forfeited by the owner, it is very likely that the number of accidents would suddenly decrease.

A curious parallel with the law of deodands was drawn from the covenant with Noah in Genesis 9:5: "And surely your blood of your lives will I require; at the hand of every beast will I require it, and at the hand of man;" and from the requirement that a homicidal animal should be put to death. These texts were considered by the medieval Church as authority for the prosecution and punishment of delinquent animals. In France, Germany and other continental countries many curious indictments were preferred against rats, mice and other destructive vermin, as well as vicious animals who killed or injured men, but as no such 
prosecutions seem to have been brought in England, the subject lies beyond our limits.

The famous privilege claimed and enjoyed for centuries by the priesthood, known as Benefit of Clergy was, according to Blackstone, founded upon the text, "Touch not mine anointed and do my prophets no harm." (4 Blacks. 365, Keilwey I8I.)

Benefit of Clergy was one of the most important heads of medieval criminal law, and meant briefly that an ordained clerk or clergyman who committed any of the graver crimes known as felonies could only be tried by an ecclesiastical court, and only be punished by such punishment, that is, penance, as such court might decree. The result was that when any one in holy orders committed a crime, he could plead his clergy, and the civil courts were then obliged to turn him over to the ecclesiastical authorities, and as he was entitled before them to be discharged by what was called compurgation, upon his swearing that he was innocent and procuring others who would swear as a matter of form that they believed him, the clerical criminal became practically immune from punishment. The doctrine soon developed that all who were sufficiently learned to be able to read were considered clerks, and entitled to benefit of clergy, and this produced a condition of things for which the only excuse is that the frightful barbarity of the criminal law was mercifully tempered. Indeed the privilege was finally extended to all who could read what was called the Neck verse, a single verse of the Bible by custom taken from the fifty-first Psalm. "Have mercy upon me, O God, according to thy loving kindness; according unto the multitude of thy tender mercies, blot out my transgressions." In the reign of Henry VII, burning in the hand was substituted for the ecclesiastical compurgation in order that the advantage of committing crime might not be enjoyed a second time, the theory apparently being that every educated man was enti- 
tled to commit one felony in the course of his life. At its best, benefit of clergy was a clumsy device to mitigate the severity of the criminal law; at its worst, it nullified the law in favor of those persons who had least excuse for breaking it. And yet Benefit of Clergy was not formally abolished until 1827,7 and 8 George IV, c. 28.

Among the ancient Hebrews the law of blood revenge caused the institution of the altar asylum. You will remember how Cain feared the Avenger after killing Abel, and how Joab in I Kings $2: 28$ fled to the Tabernacle of the Lord and caught hold of the horns of the altar. So there were also set aside Cities of Refuge as places where the innocent manslayer might flee for protection from the avenger of blood, the victim's next of kin, who might in accordance with Numbers 35 :I9 slay the murderer. According to the narrative in Deut. I9:I and 4:4I Moses selected Bezer in the Wilderness, Ramoth in Gilead and Golan in Bashan, and in Numbers, 35 :I4, three cities were provided in Canaan and three on the other side of Jordan. But intentional murder was not protected. In Exodus $2 \mathrm{I}: \mathrm{I}_{4}$ it is provided that if a man slay his neighbor with guile, "thou shalt take him from mine altar that he may die." In English law there was an interesting parallel to this legislation in what was called the privilege of sanctuary, which was closely connected with that of Benefit of Clergy. Through Benefit of Clergy the criminal escaped through the fact or fiction that he had taken orders and was a holy man; by the privilege of sanctuary he was protected by his refuge in a holy place. Felons who had fled to a church were allowed to leave it unmolested on taking oath to abjure the realm within a certain time. In other words, they were permitted to escape punishment if they went to a foreign country, taking with them their criminal habits, and leaving behind them everything else they possessed. The custom dated from Anglo-Saxon times and by a statute of $3^{2}$ 
Henry VIII, c. I2, certain towns were constituted "places of tuition and privilege" in lieu of expatriation. There were eight in all, in various parts of the Kingdom, including Westminster, but the privilege was confined to the minor offenders. Later statutes nominally abolished all privilege of sanctuaries, but they persisted for a long time, especially in London. Southwark was notorious for them, and all readers of Scott's masterly "Fortunes of Nigel" will remember the hero's adventures in Alsatia, near the Temple, which derived its pretended privilege of sanctuary from the monastery of White Friars which formerly stood there.

Whether or not tithes were due by Divine right, was a question that was warmly debated between the ecclesiastical and the common lawyers. Naturally those who demanded tithes claimed that the well-known texts in Numbers and Deuteronomy sufficiently proved the Divine will; those who had to pay the tithes just as naturally denied it. But it seems quite clear that this important right of the Church was established in direct imitation of the Hebrew law.

There are few rules of our law more familiar than that which requires a will to be proved by two witnesses, and this is only one of the many cases where the so-called "twowitness" rule applies. Although it is as difficult to trace the pedigree of a legal doctrine as the genealogy of a family, it is reasonably clear that this one is derived from Biblical authority. In Numbers $35: 30$ it is said, "One witness shall not testify against any person to cause him to die." In Deut. I7:6, "At the mouth of two witnesses or three witnesses shall he that is worthy of death be put to death, but at the mouth of one witness he shall not be put to death." In Deut. I9:I5, "At the mouth of two witnesses or at the mouth of three witnesses shall the matter be established." And in St. John, 8:I7, Christ said: "It is also written in your law that the testimony of two men is true." The same rule, "In the mouth of two or three witnesses every word 
may be established," is also quoted by Christ in St. Matthew I8:I6, and by St. Paul in II Corinthians I 3 :I, and I Timothy 5:I9. By the time of the Emperor Constantine the rule that a single witness was insufficient in law had been adopted by the Roman law, and was further developed by the Canon law of the Church. The common law of England never adopted it as a systematic rule, but as the Church courts had jurisdiction over wills, they required two witnesses for probate, on the ground that this was agreeable to the law of God, and this rule has become a part of our law of wills.

The general principle that two witnesses are necessary to prove a legal fact was adopted also by the Court of Chancery and produced there very important results in equity practice and pleading which affect our law to this day, although of a nature too technical to be interesting; and we also owe to it the rule that requires two witnesses to convict a defendant of perjury, and the provision in the Constitution of the United States, Art. 3, Sec. 3, that "no person shall be convicted of treason unless on the testimony of two witnesses to the same overt act or on confession in open court."

The command, "Whosoever sheddeth man's blood, by man shall his blood be shed," Genesis $9: 6$, was probably a fragment of the law of retaliation, or talion, stated more fully in Exodus 2I:23: "And if any mischief follow, then thou shalt give life for life, eye for eye, tooth for tooth, hand for hand, foot for foot, burning for burning, wound for wound, stripe for stripe;" and in Leviticus 24:18, "And he that killeth a beast shall make it good, beast for beast. And if a man cause a blemish in his neighbor, as he hath done so shall it be done to him." It has indeed been surmised that the law of "eye for eye, etc.," was a milder substitute for an older law which made death the universal penalty, for the natural impulse is to kill the aggressor for 
any serious injury inflicted by him. As Whitmore says in Shakespeare's Henry VI, P. 2, Act. iv, Sc. I :

"I lost mine eye in laying the prize aboard And therefore, to revenge it, shalt thou die."

At any rate, "eye for eye" is in accordance with the primitive ideas of retributive justice, tit for tat, to make the punishment fit the crime; but Christ in His Sermon on the Mount, Matthew $5: 38$, expressed His disapproval of the principle, and it was perhaps for this reason never adopted by the common law. In fact, it never seems to have obtained in any of the Germanic systems. The traces of it in Anglo-Saxon times, notably in the laws of King Alfred, were merely copied from Exodus. In cases of intentional homicide, however, the death penalty survives in most civilized countries, because it still harmonizes with the general sense of justice, and men still turn back, as did Coke and Blackstone, to the texts in the Old Testament which enjoin it, while they follow the New Testament in its abrogation of the general application of the rule. As Stephen says, "A murderer should be destroyed just as a wolf or tiger;" and Aeschylus in one of his dramas says:

"There is a law that blood, once poured on earth By murderous hands, demands that other blood Be shed in retribution."

Compare with this the verse in Genesis 4:10, "What has thou done? the voice of thy brother's blood crieth unto me from the ground."

So as to marriage and divorce. The text that makes man and wife one flesh is found in Genesis $2: 23$, but according to the Deuteronomic code, Deut. 24:I, divorce appears to have been absolutely at the pleasure of the husband. He might in the quaint phrase of the Wyclif version of Matthew I9:7 give his wife "a litil boke of forsakynge and leave off," and this little book was called in the Hebrew 
tongue by the simple but expressive monosyllable, "Get." In the Gospel of Matthew it is said that "Moses, because of the hardness of your hearts suffered you to put away your wives, but from the beginning it was not so." That men's hearts continued too hard for the full realization of this ideal Christian theory of marriage is a commonplace of history, illustrated copiously in the ecclesiastical law which could so frequently discover sufficient reasons for holding marriages void $a b$ initio. It is always a very easy matter to distinguish and refine upon texts which do not suit one's personal views upon the subject, and rely triumphantly upon others which are more agreeable.

In like manner the two-witness rule probably derived its real power from the facts, however dimly recognized, that the cumulative force of the testimony of two or more witnesses increases almost in the geometrical ratio of their number; and that the second witness can hardly tell so consistent a story that, if either be false, cross-examination will fail to detect the falsehood. The Apocryphal story of Susanna is a well-known illustration.

Thus, also, in cases where the injunctions and penalties prescribed by the Hebrew law did not satisfy the consciences of our ancestors, they were frankly disregarded. The prohibition of swine's flesh as food was never taken seriously by a nation devoted to breakfast bacon, and the punishment of death by stoning for Sabbath breaking, Numbers $15: 36$, and disobedience to parents, Deut. $21: 18$, were passed over as belonging to the "old dispensation."

So the early law of the Province of Pennsylvania gave a double portion to the eldest son in imitation of the Hebrew code in Deut. $21: I 7$, but this was soon abandoned in favor of equality of distribution.

But the Bible was quoted by all the earlier law writers and judges not merely as authority, but also by way of illustration or analogy. In many cases it is difficult to deter- 
mine just how much weight was intended to be attached to the quotations. It may perhaps be interesting to observe some such instances. I have therefore culled a few flowers from Lord Coke's writings and Blackstone's Commentaries, which authors have probably exerted more influence upon our law than any others.

Thus, in reference to the segregation of lepers in England, Coke cites the provisions of Leviticus $13: 44$, and Numbers $5: x$ as the law of God upon the subject. In speaking of twelve as the number of the jury, he observes that this number is much respected in Holy Writ, as twelve apostles, twelve stones taken by Joshua from the midst of Jordan, twelve tribes, etc., and it is interesting to note that Coke himself had twelve children. On partition by lot, he cites Numbers 26:55 and 33:54, where the Lord directed Moses to divide the land by lot. He holds that predictions of the end of the world are unlawful because, according to Acts $I: 7$, "It is not for you to know the times or the seasons." He illustrates the offence of bribery by the text, "A gift doth blind the eyes of the wise and pervert the words of the righteous," Deut. I6:I9. On duelling he refers to the words of Christ in Matthew 26:52, "Put up again thy sword into his place, for all they that take the sword shall perish with the sword," and the text, Deut. 32:35, "To me belongeth vengeance and recompense." $\mathrm{He}$ holds the modern doctrine of international law that political refugees should not be delivered up, and says that this is grounded by some on the law in Deut. 23:15, "Thou shalt not deliver unto his master the servant which is escaped from his master unto thee." In his chapter on Buildings, in 3 Inst., he quotes with approval the direction in Deut. $22: 8$, "When thou buildest a new house, then thou shalt make a battlement for thy roof, that thou bring not blood upon thine house if any man fall from thence," which probably had a deeper meaning than Lord Coke supposed. He illustrates 
the law forbidding a subject of the King of England to receive a pension from a foreign king by the text from Matthew, 6:24, "No man can serve two masters." Duelling he condemns, because God said, "Vengeance is mine, I will repay." "No man," says Coke, "ought to be condemned without answer," that is the opportunity to defend himself. $\mathrm{He}$ calls this the Divine law, and refers to the saying of Festus in Acts $25: 16$, "It is not the manner of the Romans to deliver any man to die before that he which is accused have the accusers face to face and have license to answer for himself concerning the crime laid against him," and the saying of Nicodemus, St. John 7:5I, "Doth our law judge any man before it hear him, and know what he doeth?" In mentioning the relief from jury service of men over 70 years of age, under the Statute of West. II c. 38 , he repeats, "The days of our years are three score years and ten," Psalms 90:Io. The circuits of the judges he derives from I Samuel 7:I6, where Samuel "went from year to year in circuit to Beth-el and Gilgal and Mizpeh, and judged Israel in all those places." Chapter 25 of Magna Charta concerns weights and measures; and Coke says this is founded on the law of God, citing Deut. $25: 13$, "Thou shalt not have in thy bag divers weights, a great and a small."

The Statute of Westminster, I ch. 34, against slander of the King, or the great men of the realm, is said to be in accordance with the law of God, Exodus $22: 28$, "Thou shalt not revile the gods nor curse the ruler of thy people," and Jude 8, "These filthy dreamers speak evil of dignities." And Lord Coke, in his admiration for Moses, frequently alludes to him as a judge, and the first writer of law.

These examples from Lord Coke might be multiplied indefinitely, so we shall pass to Blackstone, who, writing over a century later, uses Scripture texts in much the same way, although not to the same extent. He founds the right of property upon God's gift to Adam, Genesis I :28, of domin- 
ion over the earth and every living thing, that moveth upon it (II 2); and refers (II 6) to Isaac's reclamation of the wells which Abraham had digged, Genesis 26:15, and to the partition made between Lot and Abraham.

He illustrates the English law of inheritance by showing that males were preferred to females by the Jewish law in Numbers 27, the case decided by Moses, of the daughters of Zelophehad. In treating of the use of seals in conveyances by deed, he cites (II 305) the purchase by Jeremiah of the field of Anathoth from his nephew, where the evidence of the sale was signed and sealed. Livery of seisin he illustrates (II 3 I3) from the story of Ruth, 4:7, "Now this was the custom in former time in Israel concerning redeeming and concerning changing for to confirm all things; a man plucked off his shoe and gave it to his neighbour." He refers (II 446) to the sale of Machpelah to Abraham for 400 shekels of silver current money with the merchants, Genesis $23: 16$, and illustrates the antiquity of wills by Jacob's bequest to Joseph in Genesis $48: 22$.

In bringing to a close these superficial and desultory remarks upon certain influences of Biblical texts upon the law, it is right to add that no one should receive an erroneous impression from the harmful use of the Bible which many of the examples might without this caution seem to indicate. In law, as in religion, the letter killeth, but the spirit giveth life. Biblical texts dragged from their context and applied without any consideration of the times in which they were written, the circumstances in which they were employed, or the purposes for which they were intended, have certainly done an immense amount of harm in law as elsewhere; if regarded in the spirit of Browning's Spanish Cloister:
“There's a great text in Galatians, Once you trip on it, entails Twenty-nine distinct damnations, One sure, if another fails." 
Or as a means of divination by the Sortes Sanctorum, where the Bible was opened at hazard, and the first verse of the opened page was taken as the oracle. But no one should overlook what many writers have so often shown in words far better than any of mine, the benign and ameliorating influence of so much in the Old Testament and so much more in the New. Our attention this afternoon has been directed only to the consideration of one of the elements which has entered in a curious way, into the growth of our complex system of jurisprudence.

A word more. The Bible as a law book has not received the careful study to which it is entitled. Its theological importance, and, in later times especially, its literary interest have absorbed the attention of its readers, but there are other aspects from which it should be studied. I have confined myself to a small part of its influence in specific cases upon the development of our own law; but the student of comparative law can find in this most accessible place a rich store of material, comparable only with those systems upon which Sir Henry Maine has thrown so much light. Thus Judge Sulzberger has written upon the Hebrew Parliament, and Mr. David W. Amram, in a series of articles in the Green Bag, and in his book Leading Cases in the Bible, has shown how the Hebrew legal system was developed from the patriarchal type, and founded upon the family as the social unit, which like a corporation survived the death of its head. We find among the ancient Hebrews the blood feud, the liability of the head of the family for the crimes of his children, the correlative power which the family head had over the children even to deprive them of life and liberty; these archaic ideas and the corresponding status of women, the custom of polygamy, the rights and obligations of inheritance which are described in the Old Testament have their counterparts in the ancient laws of the Romans, the ancient Aryans and our own ancestors. 
The study of our law, especially by the historical method, should indeed be reckoned a part of a liberal education, and as such it is consistent with the purposes of our society. If it teaches nothing more, it teaches this, that imperfect as all our human institutions are, a comparison with the past shows how great has been their improvement. Every one should know something of our law, not with the minute study which the practicing lawyer is obliged to give it, but enough to enable him to appreciate what law is, what are its elementary principles, and how it came to be what it is through its long centuries of development; for our law is the protector of society, the safeguard of our rights, and the rule of our daily life. As one last quotation from the Book, it is said in Joshua 8:35, "There was not a word of all that Moses commanded which. Joshua read not before all the congregation of Israel, with the women and the little ones, and the strangers that were conversant among them." And in William Penn's Great Law of the Province of Pennsylvania, passed at Upland, on December 7,1682 , it was provided that the laws of the Province "should be printed and taught in the schools."

Bentham at a later date likewise suggested that what was good in the common law should be enacted as a statute and read in the churches and used for school exercises. So far, however, the law has not supplanted the Gospel in the churches and has not been popular in the schools or colleges.

It is not a dull, dry study. It concerns, as I said, and greatly enlivens every phase of history, politics, economics, philosophy and literature, and the student can be assured in Milton's words, that in this study "There be delights, there be recreations and jolly pastimes that will fetch the day about from sun to sun, and rock the tedious year as in a delightful dream."

John Marshall Gest. 